\title{
THE COST AND THE ECONOMIC EFFECTIVENESS ANALYSIS OF THE WINTER RAPE PRODUCTION TECHNOLOGIES (BRASSICA NAPUS L. SSP. OLEIFERA) ON HEAVY SOILS
}

\author{
LADISLAV KOVÁČ, JANA JAKUBOVÁ, DANA KOTOROVÁ
}

Plant Production Research Center Piešt’any

KOVÁČ, L. - JAKUBOVÁ, J. - KOTOROVÁ, D.: The cost and the economic effectiveness analysis of the winter rape production technologies (Brassica napus L. ssp oleiferera on heavy soils. Agriculture (Polnohospodárstvo), vol. 57, 2011, no. 4, pp. $154-165$.

Winter rape farming practices were carried out between 2007 and 2009 on heavy soils under the conditions of the East Slovak Lowland. The influence of two levels of nitrogen fertilizers and three soil tillage technologies on winter rape seed yields was monitored. The costs of growing and the growing technology cost effectiveness were evaluated.

The influence of production year 2009 on winter rape seed yield was statistically significant. The effect of conventional tillage variant on rape seed yields was more significant compared with the variant with minimum tillage. The lowest yield of oilseed rape was obtained in a non-tillage variant. Higher dose of nitrogen fertilizers had higher statistically significant effect on winter rape yield compared with lower dose of nitrogen fertilizers.

The total cost of one ton of winter rape seed varied within the monitored years, different soil tillage technologies and levels of fertilization. In average of monitored years, the lowest costs of winter rape seed production were at minimum tillage (258.37 $€ \mathrm{t}^{-1}$ for variant $\mathrm{N}_{150} ; 259.81 € \mathrm{t}^{-1}$ for variant $\mathrm{N}_{200}$ ). At direct sowing, the costs were $400.14 €$ (variant $\mathrm{N}_{150}$ ), and $372.41 €$ (variant $\mathrm{N}_{200}$ ), however, the yields were very low.

Economic effectiveness evaluation showed that the winter rape produced by direct sowing was unprofitable, either with or without subsidy. The highest economic effectiveness was achieved at the minimum tillage variant. This variant was profitable even without subsidies, using both fertilization levels, but it was more profitable at the lower level of nitrogen fertilization. The profitability of conventional tillage variant was smaller.

Key words: winter rape, yields, costs, economic effectiveness, soil tillage system, fertilisation

The growing areas of winter rape in Slovakia have expanded in recent years. The production area of this registered commodity increased lately as no other area. Winter rape utilization in the food industry and the new extended bio-fuel branch contributes to this expansion. The winter rape has permanent place in soil-climate conditions of the East Slovak Lowland, where its proportion ranges from $14 \%$ to $17 \%$. It is based on closeness of manufactory and favourable grain purchase price level area. Negative tendency, as published by Šrojtová (2002), is a displacement of winter rape cultivation from marginal areas of the East Slovak Lowland to its plain parts with higher risk of rainfall deficiency during sowing. Conventional tillage for heavy soils, utilized in plain areas, has a high tendency to create clods including high risk of dry during soil preparation.

For these reasons, the minimizing methods of soil tillage are now used in greater scope for the most extreme type, namely the direct sowing into non-tilled soil. Direct sowing (no-till) was proven for winter wheat (Balla \& Kotorová 2003) and for perennial fodder crops on arable land (Kováč \& Gejguš 2002). The significant production parameters were achieved by minimum tillage for spring barley (Danilovič \& Šoltysová 2007), grain maize (Hnát 2009) and legumes

Ing. Ladislav Kováč, PhD., Plant Production Research Center Piešt’any - Agroecology Research Institute, 07101 Michalovce, Špitálska 1273, Slovak Republic. E-mail: kovac@minet.sk 
(Šariková \& Hnát 2005) in comparison to the direct sowing.

Basic soil treatment for winter rape begins with forecrop harvest. The uniform distribution of post-harvest residues is important for the utilization of direct sowing and minimum tillage. The problem, which originates at the management of post-harvest residues, can impact the completeness of winter rape stand (Šařec et al. 2009). The essential precondition for stable high rape seed yields achievement requires complete stand with optimal amount of plants (Zubal 2003; Jambor 2007).

From economic point of view the cultivation of winter rape is profitable when favourable realisation prices are in effect. But it is necessary to keep the seed yield per hectare at 3 ton level, also not to increase the cost of rape growing and to optimize growing technologies. It is possible to affect the economy of winter rape cultivation by optimizing the growing technologies.

By means of technical, organizational and technological measures it is possible to reduce the specific energy consumption in chosen technological procedures in order to increase economic effectiveness and so to improve quality of production and to reduce negative agricultural production impact on soil and environment (Syrový et al. 2008). The strong energy and economy savings will be achieved by the implementation of energy saving operations, work and technological proce- dures. Similarly, according to Nozdrovický and Rataj (2001), the costs consist of input prices which are not controlled by farmers (purchase price, rental, fees), but there are cost items which are controlled by farmers (amount of operations, set, doses, e.g.).

The aim of this contribution was the costs analysis and the evaluation of winter rape cultivation effectiveness with two levels of nitrogen nutrition and three tillage technologies on heavy soils of the East Slovak Lowland.

\section{MATERIAL AND METHOD}

Field experiments with different soil cultivation were carried out between 2006 and 2009 at experimental place in Milhostov, the unit of Plant Production Research Center Piešt'any - Agroecology Research Institute Michalovce, on heavy Gleyic Fluvisol soil at the altitude of $101 \mathrm{~m}$.

Gleyic Fluvisol $\left(\mathrm{FM}_{\mathrm{G}}\right)$ in Milhostov is characterized as heavy, clay-loamy soils with average content of clay particles higher than 53\%. Gleyic Fluvisol was formed on heavy alluvial sediments during the longtime contact with groundwater and surface. The topsoil has lump aggregate structure with high binding ability and it has a weak perviousness through the whole profile. A layer of dark grey/yellow grey clay is situated in the depth $0.7-0.8 \mathrm{~m}$ of soil profile. The agronomical

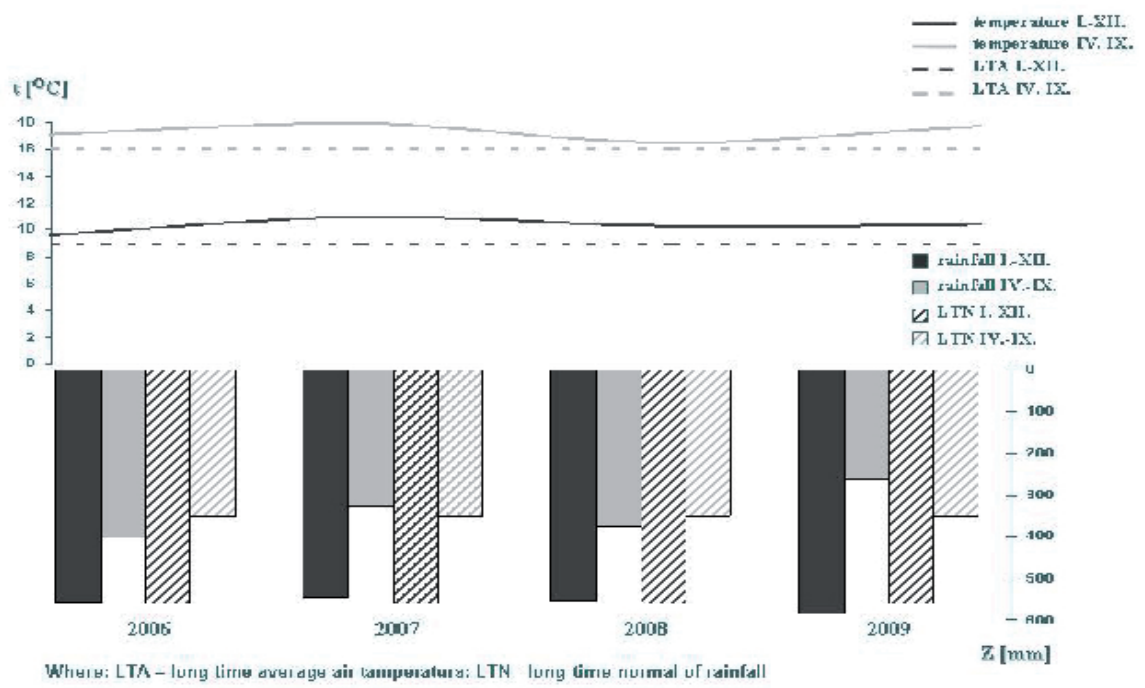

Fig. 1. Weather conditions of experimental years 
properties of Gleyic Fluvisol are significantly influenced by the high content of clay particles.

The experimental locality is characterized as warm and very dry lowland continental climate region $\mathrm{T} 03$ (Linkeš et al. 1996). Weather conditions at the site in experimental years are shown in Figure 1.

The study was realized in Milhostov in field stationary experiment with appropriate crop rotation. The winter wheat was a forecrop for winter rape in the rotation.

The stands of winter rape - cultivar Californium - were established with two levels of fertilisation:

- $\mathrm{N}_{150}-150 \mathrm{~kg} \mathrm{ha}^{-1}$ of nitrogen;

- $\mathrm{N}_{200}-200 \mathrm{~kg} \mathrm{ha}^{-1}$ of nitrogen.

Seed rate of winter rape was 650 thousand germinated seeds. Average stand density was 50 plants per $1 \mathrm{~m}^{2}$.

Phosphorus and potassium doses were equal using both levels of nitrogen, namely $\mathrm{P}-50 \mathrm{~kg} \mathrm{ha}^{-1}$ and $\mathrm{K}$ $-150 \mathrm{~kg} \mathrm{ha}^{-1}$. Nitrogen was used as a form of ammophos $(12.0 \% \mathrm{~N})$ and ammonium nitrate $(27.0 \% \mathrm{~N})$. The phosphorus as ammophos $(22.5 \% \mathrm{P})$ and potassium as potassium chloride $(49.8 \% \mathrm{~K})$ were used.

Three soil tillage technologies were examined as follows:

- CT (conventional tillage) - stubble ploughing, ploughing, smoothing, harrowing and sowing by sowing machine Pneusej Accord;

- MT (minimum tillage) - stubble ploughing by skive cultivator, soil preparation by skive cultivator before sowing and sowing by sowing machine Pneusej Accord;

- NT (non-tillage) - direct sowing without ploughing by sowing machine Great Plains.

The harvest was realized by small-plot harvester. The yields of winter rape seeds were recalculated to $92 \%$ dry matter. The multi factorial analysis of variance ANOVA from statistical package STATGRAPHICS was used.

The norms with reference to Kavka (2006) and Abrham et al. (2007) were used for cost evaluation for the set of machines and working procedures. It was recalculated in conditions of heavy soils of the East Slovak Lowland.

The variable costs consist of:

- Personal costs of drivers and workers (data were obtained from Statistical Office of the Slovak Republic);

- Costs of fuel, oils and lubricants were calculated from real prices of diesel fuel purchased for experimental workplace Milhostov, increased by $10 \%$ for consumed lubricants and oils;

- Repair and maintenance costs (with reference to Abrham et al. 2007);

- Material costs, calculated from the prices of seed, mineral fertilizers and pesticides in a given year, purchased for experimental workplace Milhostov.

The fixed costs consist of:

- Fixed costs of energetic source and connected mechanisms (depreciation, taxes and fees, insurance, warehousing mechanisms, paid interest on capital) according to norms (Abrham et al. 2007).

The total production was calculated on base of real production for regional processor according to approved contract price.

Subsidy consists of real payments for concrete land-register (Milhostov), namely as unified payment per area (SAPS - Single Area Payment Scheme) and national complementary payments (CNDPs - Complementary Nation Direct Payments).

Economic effectiveness of production technologies was evaluated in accordance with methodology Poláčková et al. (2010) in two variants as follows:

1. The calculation of economic effectiveness without subsidy:

production $\left[€ \mathrm{ha}^{-1}\right]=$ yield $\left[\mathrm{t} \mathrm{ha} \mathrm{a}^{-1}\right] \times$ realization price $\left[€ \mathrm{t}^{-1}\right]$;

profit/loss $\left[€\right.$ ha $\left.^{-1}\right]=$ production $\left(€\right.$ ha $\left.^{-1}\right)-$ costs $\left[€ \mathrm{ha}^{-1}\right]$

profit/loss $\left[€ \mathrm{t}^{-1}\right]=$ realization price $\left(€ \mathrm{t}^{-1}\right)-$ costs $\left[€ \mathrm{t}^{-1}\right]$

profitability of costs per 1 hectare [\%] $=[$ profit/loss : costs] $\times 100$;

return threshold for null profitability $\left[\mathrm{t} \mathrm{ha}^{-1}\right]=$ costs $\left[€\right.$ ha $\left.^{-1}\right]$ : realization price $\left[€ \mathrm{t}^{-1}\right]$.

2. The calculation of economical effectiveness with subsidy:

production $\left[€ \mathrm{ha}^{-1}\right]=\operatorname{crop}\left[\mathrm{t} \mathrm{ha}^{-1}\right] \times$ realization price $\left[€ \mathrm{t}^{-1}\right]$ 
profit/loss $\left[€ \mathrm{ha}^{-1}\right]=$ production $\left[€ \mathrm{ha}^{-1}\right]+$ subsidies $\left[€\right.$ ha $\left.^{-1}\right]$ - costs $\left[€\right.$ ha $\left.^{-1}\right]$;

profit/loss $\left[€ \mathrm{t}^{-1}\right]=$ realization price $\left[€ \mathrm{t}^{-1}\right]+$ subsi$\operatorname{dies}\left[€ \mathrm{t}^{-1}\right]-\operatorname{costs}\left[€ \mathrm{t}^{-1}\right]$.

Where:

subsidies $\left[€ \mathrm{t}^{-1}\right]=$ subsidies $\left[€\right.$ ha $\left.^{-1}\right] /$ crop $\left[\mathrm{t} \mathrm{ha}^{-1}\right]$; profitability of costs per 1 hectare [\%] = [profit/loss : costs] $\times 100$;

return threshold for null profitability $\left[\mathrm{t} \mathrm{ha}^{-1}\right]=$ (costs $\left[€\right.$ ha $\left.^{-1}\right]$ - subsidies $\left[€\right.$ ha $\left.\left.^{-1}\right]\right)$ : realization price $\left[€ \mathrm{t}^{-1}\right]$.

The methods of analysis and synthesis, induction, deduction and comparison were used in the evaluation.

\section{RESULTS AND DISCUSSION}

\section{Seed yield}

The seed yield of winter rape is the most important monitored parameter in the evaluation. The productive year with its meteorological factors had significant impact on final yield in monitored years 2007-2009 (Fig. 1). The growing year 2009 had significant impact on winter rape crop, compared to years 2007 and 2008 when the warm and wet winter between 2008 and 2009 helped to that and stands of winter rape overwintered well. Due to heavy soil ability to retain water for a long time without rain, stand of winter rape withstood very warm and extremely dry weather from the end of March to mid May 2009. Heavy rains in second half of May and small temperature reduction caused massive yields increase compared to previous years. The highest yield during experimental period was achieved in that year using conventional variant with more intensive nitrogen fertilization $\left(4.01 \mathrm{t} \mathrm{ha}^{-1}\right)$ (Table 1$)$. The significant effect of weather on winter rape yield in conditions of the East Slovak Lowland was confirmed by Šrojtová (2005). The effect of weather conditions is a crucial factor for rape seed yield formation. Also Jambor (2007) mentioned the extremely strong weather conditions impact on yield.

The highest yields of oilseed rape were achieved at variant with conventional tillage technology (Table 1), at both levels of nitrogen fertilization. On the other hand, the lowest yields were obtained by direct sowing into unploughed soil. For the variant of direct sowing in year 2008, the lowest yield in absolute and relative values was achieved, when lower fertilization dosage, namely $1.46 \mathrm{t} \mathrm{ha}^{-1}$ was used. It represented $34.5 \%$ of yield using conventional tillage variant. The yield 1.77 $\mathrm{t}$ ha ${ }^{-1}$ was achieved for higher fertilization level and it reached $48.5 \%$ of conventional tillage variant. It is related to higher amount of post-harvest residues, which remained after forecrop in concrete year. At direct sowing (non-tillage variant) the rape seeds were not applied into adequate depth; they were not evenly distributed into the soil and also inhibiting effect of straw

$\mathrm{T}$ a

Winter rape seed yield in experimental years $\left[\mathrm{tha}^{-1}\right]$

\begin{tabular}{|c|c|c|c|c|c|c|c|c|}
\hline \multirow{3}{*}{$\begin{array}{l}\text { Fertilization } \\
\qquad(\mathrm{F})\end{array}$} & \multirow{3}{*}{$\begin{array}{c}\text { Soil } \\
\text { tillage }\end{array}$} & \multicolumn{6}{|c|}{ Experimental years $(\mathrm{Y})$} & \multirow{3}{*}{$\bar{x} Y$} \\
\hline & & \multicolumn{2}{|c|}{2007} & \multicolumn{2}{|c|}{2008} & \multicolumn{2}{|c|}{2009} & \\
\hline & & abs. & rel. \% & abs. & rel. $\%$ & abs. & rel. $\%$ & \\
\hline \multirow{4}{*}{$\mathrm{N}_{150}$} & $\mathrm{CT}$ & 3.08 & 100.00 & 3.36 & 100.00 & 3.56 & 100.00 & 3.33 \\
\hline & MT & 2.97 & 96.40 & 3.34 & 99.40 & 3.26 & 91.60 & 3.19 \\
\hline & NT & 2.54 & 82.50 & 1.46 & 34.50 & 2.34 & 65.70 & 2.11 \\
\hline & $\overline{\mathrm{X}} \mathrm{F}$ & 2.86 & 93.00 & 2.72 & 78.00 & 3.05 & 85.80 & 2.87 \\
\hline \multirow{4}{*}{$\mathrm{N}_{200}$} & $\mathrm{CT}$ & 3.13 & 100.00 & 3.65 & 100.00 & 4.01 & 100.00 & 3.60 \\
\hline & MT & 3.07 & 98.1 & 3.45 & 94.50 & 3.51 & 87.50 & 3.34 \\
\hline & NT & 2.84 & 90.7 & 1.77 & 48.50 & 2.56 & 63.80 & 2.39 \\
\hline & $\overline{\mathrm{x}} \mathrm{F}$ & 3.01 & 96.3 & 2.96 & 81.00 & 3.36 & 83.80 & 3.11 \\
\hline
\end{tabular}

$\mathrm{CT}$ - conventional tillage, MT - minimum tillage, NT - non-tillage 
to germination and early development of plants was observed. Important decrease of winter oilseed rape yield was caused by incomplete plants. Many authors, for example Šařec et al. (2009) and others, mentioned the problem with the management of post-harvest residues. Also our results from experiments with the usage of different tillage technologies resulted in higher average yields on these variants, where negative effect of straw on winter rape germination and its development was eliminated.

From the analysis of variance (Table 2) it becomes clear that soil tillage has statistically significant effect on winter oilseed rape yield. The conventional tillage with the highest rape oilseed yield had statistically more significant effect on oilseed rape yield than minimum tillage variant and non-tillage variant which resulted in lower yields.

Higher intensity of nitrogen fertilization increased winter oilseed rape yield in all of observed years and at all soil tillage variants. Our results indicate the nitrogen fertilization dose $200 \mathrm{~kg} \mathrm{ha}^{-1}$ had statistically more significant impact on yield than the nitrogen fertilization dose $150 \mathrm{~kg} \mathrm{ha}^{-1}$. The similar results published Kátai $(2009,2010)$, who increased the yield on hectare by increasing of nitrogen dose during winter rape experiments. But unlike our results, the production parameters accomplished on loosing and disking variant were higher than on ploughing variant.

Comparison of labour and diesel fuel consumption at soil tillage technologies

The detailed measures of individual soil tillage technologies per 1 ha for winter rape are described in Table 3. For conventional soil tillage 19 measures were needed. On the other hand, only 14 measures were needed to be performed for minimum tillage and nontillage. The same number of measures for minimum tillage and non-tillage was due to the replacement of low-till (minimum tillage) by total herbicide application (non-tillage). There were marked human work costs savings by using non-tillage technologies. The labour requirement with 19 measures for conventional tillage was 9.40 hours. The 14 measures for minimum tillage took only 6.25 hours and for non-tillage (direct sowing) it represented 6.38 hours. Slightly shorter time was spent using minimum tillage ( $\Delta=0.13$ hours). The reason for that was that the time for soil preparation by loosening (minimum tillage) was shorter than the time for total herbicide spraying and direct sowing. Significant savings were due to the use of diesel fuel. For conventional tillage on heavy soils it was 112.90 1 of diesel fuel per hectare. This was caused by high fuel consumption for stubble breaking, ploughing and soil preparation before sowing. The diesel fuel con-

$\mathrm{T}$ a b 1 e 2

Multifactor analysis and multiple comparing LSD-test of winter rape seed yield

\begin{tabular}{|c|c|c|c|c|c|c|c|c|}
\hline $\begin{array}{l}\text { Source of } \\
\text { variability }\end{array}$ & $\begin{array}{l}\text { Degree of } \\
\text { freedom }\end{array}$ & F-test & Signification & $\begin{array}{l}\text { Yield } \\
{\left[\mathrm{t} \mathrm{ha}^{-1}\right]}\end{array}$ & \multicolumn{4}{|c|}{ Group of homogeneity } \\
\hline Fertilization & 1 & 9.7 & ++ & $\begin{array}{l}2.87 \\
3.11\end{array}$ & $\begin{array}{l}\mathrm{N}_{150} \\
\mathrm{~N}_{200}\end{array}$ & $\mathrm{x}$ & $\mathrm{x}$ & \\
\hline Tillage & 2 & 102.6 & ++ & $\begin{array}{l}2.25 \\
3.27 \\
3.47\end{array}$ & $\begin{array}{l}\text { NT } \\
\text { MT } \\
\text { CT }\end{array}$ & $\mathrm{x}$ & $\mathrm{x}$ & $\mathrm{x}$ \\
\hline Year & 2 & 8.8 & ++ & $\begin{array}{l}2.84 \\
2.94 \\
3.21\end{array}$ & $\begin{array}{l}2008 \\
2007 \\
2009\end{array}$ & $\mathrm{x}$ & $\mathrm{x}$ & \\
\hline Rezidual & 6 & & & & & & & \\
\hline Total & 29 & & & & & & & \\
\hline
\end{tabular}




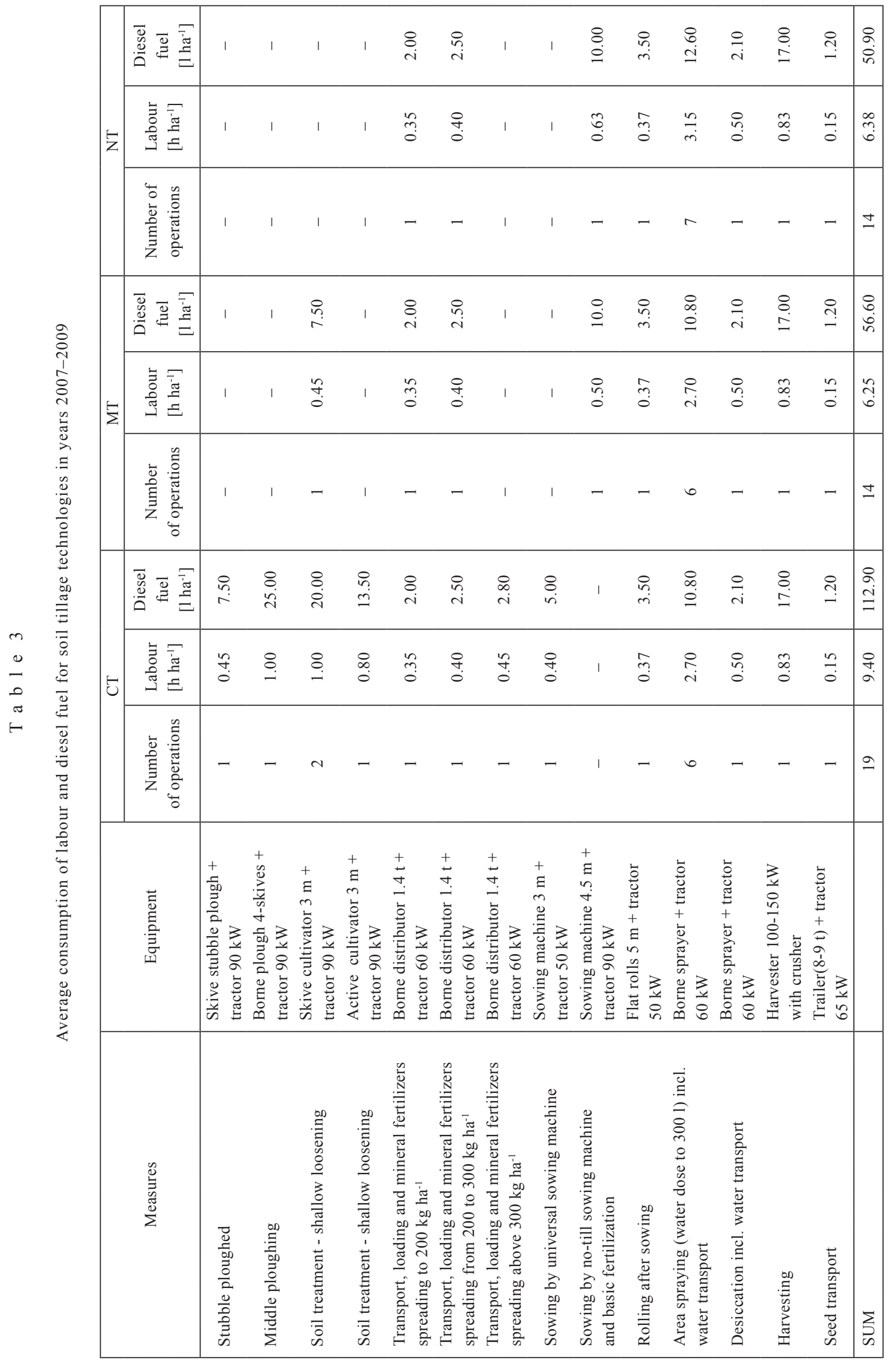




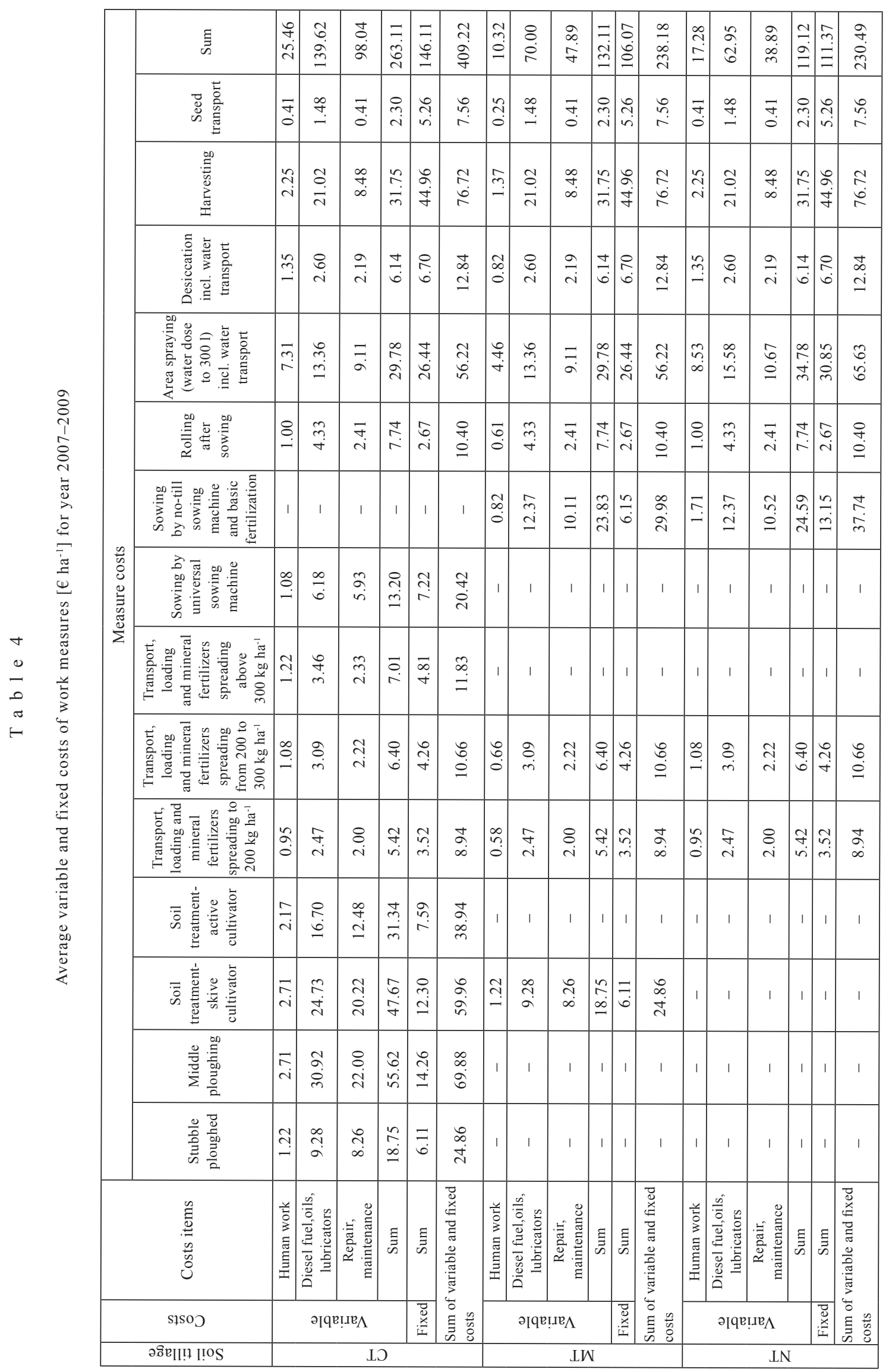


sumption was decreased at minimum tillage down to near half (56.6 1) and by non-tillage down to over half (50.90 1). These savings are much higher than savings published by Šařec el al. (2009), who observed 16.3\% saving of diesel fuel by using minimum tillage against conventional ones and decrease of labour by $32.1 \%$. Also Dobek (2005a) presents 20.69\% saving of diesel fuel using minimum tillage against conventional tillage and decrease of labour by $43.13 \%$.

\section{Measures costs}

Average calculated variable and fixed costs of work measures per hectare for years 2007-2009 are shown in Table 4. The individual year costs varied depending on wage increase and fuel price changes.

The average total costs of measures (Table 4) using conventional tillage were $409.22 € \mathrm{ha}^{-1}$. More than half of these costs $\left(214.06 € \mathrm{ha}^{-1}\right)$ were spent on measures related to soil treatment - stubble breaking, middle ploughing, loosening and sowing. The costs of diesel fuel, oils and lubricants amounted to $139.62 € \mathrm{ha}^{-1}$, representing the highest items in the cost structure. Compared to this item, the measures costs were relatively low, only $25.46 € \mathrm{ha}^{-1}$. At minimum technology the average total costs were lower $-238.18 € \mathrm{ha}^{-1}$. The costs were reduced significantly by omitting stubble break-

$\mathrm{T}$ a b 1 e 5

Total costs of winter rape cultivation

\begin{tabular}{|c|c|c|c|c|c|c|c|c|}
\hline \multirow{2}{*}{ Year } & \multirow{2}{*}{ Soil tillage } & \multirow{2}{*}{ Fertilization } & \multicolumn{3}{|c|}{ Variable costs $\left[€ \mathrm{ha}^{-1}\right]$} & \multirow{2}{*}{$\begin{array}{c}\text { Fixed } \\
\text { costs }\end{array}$} & \multicolumn{2}{|c|}{ Total costs } \\
\hline & & & Material & $\begin{array}{c}\text { Mechanical } \\
\text { work }\end{array}$ & Sum & & $€ \mathrm{ha}^{-1}$ & $€ \mathrm{t}^{-1}$ \\
\hline \multirow{6}{*}{2007} & \multirow{2}{*}{$\mathrm{CT}$} & $\mathrm{N}_{150}$ & 535.77 & 250.32 & 786.09 & 146.11 & 932.20 & 302.66 \\
\hline & & $\mathrm{N}_{200}$ & 574.83 & 250.32 & 825.15 & 146.11 & 971.26 & 310.31 \\
\hline & \multirow{2}{*}{ MT } & $\mathrm{N}_{150}$ & 535.77 & 124.65 & 660.42 & 106.07 & 766.49 & 258.08 \\
\hline & & $\mathrm{N}_{200}$ & 574.83 & 124.65 & 699.48 & 106.07 & 805.55 & 262.39 \\
\hline & \multirow{2}{*}{ NT } & $\mathrm{N}_{150}$ & 568.97 & 111.89 & 680.86 & 111.37 & 792.23 & 311.90 \\
\hline & & $\mathrm{N}_{200}$ & 608.03 & 111.89 & 719.92 & 111.37 & 831.29 & 292.71 \\
\hline \multirow{6}{*}{2008} & \multirow{2}{*}{$\mathrm{CT}$} & $\mathrm{N}_{150}$ & 670.36 & 274.54 & 944.90 & 146.11 & 1091.01 & 324.71 \\
\hline & & $\mathrm{N}_{200}$ & 722.44 & 274.54 & 996.98 & 146.11 & 1143.09 & 313.18 \\
\hline & \multirow{2}{*}{ MT } & $\mathrm{N}_{150}$ & 670.36 & 138.17 & 808.53 & 106.07 & 914.60 & 273.83 \\
\hline & & $\mathrm{N}_{200}$ & 722.44 & 138.17 & 860.61 & 106.07 & 966.68 & 280.20 \\
\hline & \multirow{2}{*}{ NT } & $\mathrm{N}_{150}$ & 701.23 & 124.73 & 825.96 & 111.37 & 937.33 & 642.01 \\
\hline & & $\mathrm{N}_{200}$ & 753.31 & 124.73 & 878.04 & 111.37 & 989.41 & 558.99 \\
\hline \multirow{6}{*}{2009} & \multirow{2}{*}{$\mathrm{CT}$} & $\mathrm{N}_{150}$ & 551.91 & 264.48 & 816.39 & 146.11 & 962.50 & 270.37 \\
\hline & & $\mathrm{N}_{200}$ & 594.10 & 264.48 & 858.58 & 146.11 & 1004.69 & 250.55 \\
\hline & \multirow{2}{*}{ MT } & $\mathrm{N}_{150}$ & 551.91 & 133.51 & 685.42 & 106.07 & 791.49 & 242.79 \\
\hline & & $\mathrm{N}_{200}$ & 594.10 & 133.51 & 727.61 & 106.07 & 833.68 & 237.52 \\
\hline & \multirow{2}{*}{ NT } & $\mathrm{N}_{150}$ & 575.22 & 120.73 & 695.95 & 111.37 & 807.32 & 345.01 \\
\hline & & $\mathrm{N}_{200}$ & 617.41 & 120.73 & 738.14 & 111.37 & 849.51 & 331.84 \\
\hline \multirow{6}{*}{$\bar{x}$ 2007-2009 } & \multirow{2}{*}{$\mathrm{CT}$} & $N_{150}$ & 586.01 & 263.11 & 849.13 & 146.11 & 995.24 & 298.57 \\
\hline & & $\mathrm{N}_{200}$ & 630.46 & 263.11 & 893.57 & 146.11 & 1039.68 & 289.07 \\
\hline & \multirow{2}{*}{ MT } & $\mathrm{N}_{150}$ & 586.01 & 132.11 & 718.12 & 106.07 & 824.19 & 258.37 \\
\hline & & $\mathrm{N}_{200}$ & 630.46 & 132.11 & 762.57 & 106.07 & 868.64 & 259.81 \\
\hline & \multirow{2}{*}{ NT } & $\mathrm{N}_{150}$ & 615.14 & 119.12 & 734.26 & 111.37 & 845.63 & 400.14 \\
\hline & & $\mathrm{N}_{200}$ & 659.58 & 119.12 & 778.70 & 111.37 & 890.07 & 372.41 \\
\hline
\end{tabular}

$\mathrm{N}_{150}$ - nitrogen fertilization $150 \mathrm{~kg} \mathrm{ha}^{-1} \mathrm{~N} ; \mathrm{N}_{200}-$ nitrogen fertilization $200 \mathrm{~kg} \mathrm{ha}^{-1} \mathrm{~N}$ 
ing, loosening and ploughing. The highest item of work measure costs $-76.72 €$ ha $^{-1}$ - was oilseed rape yield harvest by combine harvester. The direct sowing average costs were $230.49 € \mathrm{ha}^{-1}$ and they were by $7.69 €$ $\mathrm{ha}^{-1}$ less than minimum tillage costs. The highest costs $\left(65.63 € \mathrm{ha}^{-1}\right)$ were also at pesticides application. In average the direct sowing on NT variant expended costs were $37.74 €$ ha $^{-1}$ and it was more than at conventional $\left(20.42 € \mathrm{ha}^{-1}\right)$ and at minimum technology $\left(1.71 € \mathrm{ha}^{-1}\right)$. Dobek (2005b) obtained similar results by observation that the soil treatment costs using conventional tillage represented more than $50 \%$ of work measure costs and by using minimum tillage the highest cost item was the winter rape harvest by combined harvester.

The labour costs of soil tillage technologies are significantly less than other cost items. It is related to the observation presented by Buchta (2010), that labour costs per employee in agriculture are the ones of the lowest among all the industries. At the same time, the average wage of agricultural manual workers represents $70 \%$ of the average wages of managers, technical workers and administrative workers.

\section{Total costs}

The total costs of winter rape cultivation are presented in Table 5. During the observed years, the highest total costs per hectare were in year 2008. That is related to high material costs of that year, namely because of extreme increase of fertilizer prices and increased mechanized work costs, which were higher because of wage and mainly diesel fuel prices increase. The total costs per hectare were decreased down from 123.11-139.9 $€ \mathrm{ha}^{-1}$. Decrease of commercial fertilizers and diesel fuel prices in year 2009 caused total costs decrease down to between 123.11-139.90 € $\mathrm{ha}^{-1}$ compared to year 2008. Material costs had the highest impact on total costs; they represented more than 50\% of total costs. Comparing the soil tillage technologies and nitrogen fertilizer in all of observed years, the lowest total costs were at minimum tillage. In accordance with average values of years 2007-2009, the minimum tillage costs with lower nitrogen fertilizer level were $824.19 €$ ha $^{-1}$ and with higher nitrogen fertilizer level $868.64 €$ ha $^{-1}$. The highest total costs were at conventional tillage $-995.24 € \mathrm{ha}^{-1}$ with lower nitrogen fertilizer level and $1039.68 €$ ha $^{-1}$ with higher nitrogen

$\mathrm{T}$ a b 1 e 6

Economic effectiveness of winter rape cultivation - years 2007-2009

\begin{tabular}{|c|c|c|c|c|c|c|c|c|c|c|}
\hline \multirow[t]{2}{*}{ Subsidy } & \multirow[t]{2}{*}{$\begin{array}{l}\text { Soil } \\
\text { tillage }\end{array}$} & \multirow[t]{2}{*}{ Fertilization } & Yield & $\begin{array}{c}\text { Realization } \\
\text { price }\end{array}$ & Production & Subsidy & Costs & $\begin{array}{c}\text { Profit }+/ \\
\text { Loss - }\end{array}$ & $\begin{array}{c}\text { Profitability } \\
\text { of costs per } \\
\text { ha }\end{array}$ & $\begin{array}{c}\text { Yield } \\
\text { threshold }\end{array}$ \\
\hline & & & {$\left[\mathrm{t} \mathrm{ha}^{-1}\right]$} & {$\left[€ \mathrm{t}^{-1}\right]$} & {$\left[€ \mathrm{ha}^{-1}\right]$} & {$\left[€ \mathrm{ha}^{-1}\right]$} & {$\left[€ \mathrm{ha}^{-1}\right]$} & {$\left[€ \mathrm{ha}^{-1}\right]$} & {$[\%]$} & {$\left[\mathrm{t} \mathrm{ha}^{-1}\right]$} \\
\hline \multirow{6}{*}{ 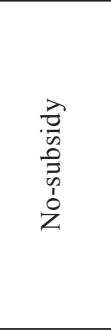 } & \multirow{2}{*}{$\mathrm{CT}$} & $\mathrm{N}_{150}$ & 3.33 & 305.67 & 1018.63 & 0.00 & 995.24 & +23.39 & 2.35 & 3.26 \\
\hline & & $\mathrm{N}_{200}$ & 3.60 & 305.67 & 1099.14 & 0.00 & 1039.68 & +59.46 & 5.72 & 3.40 \\
\hline & \multirow{2}{*}{ MT } & $\mathrm{N}_{150}$ & 3.19 & 305.67 & 982.04 & 0.00 & 824.19 & +157.84 & 19.15 & 2.70 \\
\hline & & $\mathrm{N}_{200}$ & 3.34 & 305.67 & 1026.08 & 0.00 & 868.64 & +157.44 & 18.12 & 2.84 \\
\hline & \multirow{2}{*}{ NT } & $\mathrm{N}_{150}$ & 2.11 & 305.67 & 611.94 & 0.00 & 845.63 & -233.69 & & 2.77 \\
\hline & & $\mathrm{N}_{200}$ & 2.39 & 305.67 & 698.56 & 0.00 & 890.07 & -191.51 & -21.52 & 2.91 \\
\hline \multirow{6}{*}{ 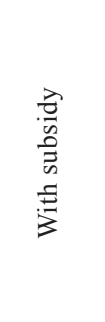 } & \multirow{2}{*}{$\mathrm{CT}$} & $\mathrm{N}_{150}$ & 3.33 & 305.67 & 1018.63 & 151.66 & 995.24 & +175.05 & 17.59 & 2.76 \\
\hline & & $\mathrm{N}_{200}$ & 3.60 & 305.67 & 1099.14 & 151.66 & 1039.68 & +211.12 & 20.31 & 2.91 \\
\hline & \multirow{2}{*}{ MT } & $\mathrm{N}_{150}$ & 3.19 & 305.67 & 982.04 & 151.66 & 824.19 & +309.50 & 37.55 & 2.20 \\
\hline & & $\mathrm{N}_{200}$ & 3.34 & 305.67 & 1026.08 & 151.66 & 868.64 & +309.10 & 35.58 & 2.35 \\
\hline & \multirow{2}{*}{ NT } & $\mathrm{N}_{150}$ & 2.11 & 305.67 & 611.94 & 151.66 & 845.63 & -82.03 & -9.70 & 2.27 \\
\hline & & $\mathrm{N}_{200}$ & 2.39 & 305.67 & 698.56 & 151.66 & 890.07 & -39.85 & -4.48 & 2.42 \\
\hline
\end{tabular}


fertilizer level. Comparing costs (average of observed years) related to level of nitrogen fertilizer, the total costs with nitrogen dose $200 \mathrm{~kg} \mathrm{ha}^{-1}$ (higher dose) were higher by $44.44 €$ ha $^{-1}$ while using conventional tillage and they were higher by $44.45 € \mathrm{ha}^{-1}$ when using minimum tillage.

The total costs of 1 tone winter oilseed rape production were different with reference to particular years, soil tillage technologies and fertilization. Using average values of observed years, the lowest costs of oilseed rape production were with minimum tillage $-258.37 € \mathrm{t}^{-1}$ at variant $\mathrm{N}_{150}$ and $259.81 € \mathrm{t}^{-1}$ at variant $\mathrm{N}_{200}$. One tone of oilseed rape was produced for 400.14 $€\left(\mathrm{~N}_{150}\right)$ resp. $372.41 €\left(\mathrm{~N}_{200}\right)$ at direct sowing variant, when the oilseed rape yields were very low. One tone of winter oilseed rape was produced extremely expensively in 2008 at this variant, namely $642.01 €\left(\mathrm{~N}_{150}\right)$ resp. $558.99 €\left(\mathrm{~N}_{200}\right)$.

In 2007 the average costs of winter rape cultivation in Slovakia were $816.44 €$ ha $^{-1}$ (Kubanková \& Burianová 2008). These published costs were higher then the costs in our experiment in 2007 with minimum tillage, but lower than costs with conventional tillage experiment. It indicates lower intensity of winter rape cultivation in agricultural practise, which matches average yield per hectare $2.34 \mathrm{t} \mathrm{ha}^{-1}$. In 2008 the winter rape cultivations costs increased to $962.16 € \mathrm{ha}^{-1}$ for Slovak Republic. Our calculation in reference to our experiment in 2008 confirmed this increase. Comparing to Slovak average values, lower costs in our experiment were achieved with minimum tillage and direct sowing with lower nitrogen dose. The Slovak average cost of one tone winter rape seed was $331.77 € \mathrm{t}^{-1}$ in mentioned year. In our experiment, one tone of rape was produced with lower costs at minimum tillage and conventional tillage as well.

\section{Economic efficiency of production}

Average economic efficiency of winter rape cultivation of years 2007-2009 is presented in Table 6. An average realisation price of winter oilseed rape during three experimental years was $305.67 € \mathrm{ha}^{-1}$. The winter rape cultivation by direct sowing technology was unprofitable, even with the subsidy. It was the effect of very low hectare yields reached with this technology. The winter oilseed rape yield at level $2.27 \mathrm{t} \mathrm{ha}^{-1}$ at $\mathrm{N}_{150}$, resp. $2.42 \mathrm{t} \mathrm{ha}^{-1}$ at $\mathrm{N}_{200}$ would be sufficient at non-tillage variant to reach null profitability of costs with subsidy $151.66 € \mathrm{ha}^{-1}$. The highest economic efficiency was determined for minimum tillage variant. This variant was profitable also without subsidy and at both fertilizer. The profit $309.50 € \mathrm{ha}^{-1}$ was reached on this variant at lower nitrogen fertilizer with subsidy and profit $309.10 € \mathrm{ha}^{-1}$ at higher nitrogen fertilizer. The variant with lower level of nitrogen fertilizer was more profitable and profitability of costs per hectare with subsidy reached $37.55 \%$. The conventional variant was less profitable. The profit at this variant with subsidy was $175.05 € \mathrm{ha}^{-1}\left(\right.$ at $\mathrm{N}_{150}$ ), resp. 211.12 $€ \mathrm{ha}^{-1}\left(\right.$ at $\left.\mathrm{N}_{200}\right)$. Unlike non-tillage variant, at conventional tillage, higher profitability per hectare (20.31\%) was attained using higher nitrogen fertilization level, compared to $17.59 \%$ while using lower fertilisation level. Serenčéš et al. (2009) and Duričová and Chrastinová (2010) found out strong dependence between subsidies and farming results. Based on long-term analyses the winter rape cultivation without subsidies with existing intensity is uneconomic. Only producers with yields over $3 \mathrm{t} \mathrm{ha}^{-1}$ will be competitive in the future of world market liberalisation.

\section{CONCLUSIONS}

From the results obtained between 2007 and 2009 we make the following statements about the cost and economic effectiveness analysis of the winter rape production technologies on heavy soils.

The production year, conventional tillage and level of nitrogen fertilization had statistically significant effect on winter oilseed rape yield.

Labour and diesel fuel consumption were significantly lower at minimum tillage and non-tillage technologies in comparison with conventional tillage. The differences for labour requirements for different soil tillage were as follows: $\Delta \mathrm{CT}-\mathrm{MT}=3.15$ hours per hectare, $\Delta \mathrm{CT}-\mathrm{NT}=3.02$ hours per hectare. The consumption of diesel fuel for minimum tillage was 56.3 litres per hectare, which was lower in comparison with conventional tillage. For non-tillage it was 62.0 litres per hectare.

Costs for measures in observed years changed in line with the wages and fuel prices progress. The highest costs for measures were determined in year 2008 when fuel prices markedly increased. In average the highest costs were ascertained for conventional tillage 
(409.22 € per hectare), then followed minimum tillage (238.18€ per hectare) and non-tillage with direct sowing (230.49€ per hectare).

The fertilizers and pesticides costs were the highest items among total costs. In average of years 2007-2009 the costs for fertilizers reached $58.66 \%$ up to $64.28 \%$ from total costs. The costs of pesticides were in range between $27.97 \%-33.40 \%$ from the total costs.

The total costs for production of 1 ton of winter oilseed rape yield varied in individual years, at soil tillage technologies and levels of nitrogen fertilizer. In average of observed years the lowest total costs for production of winter oilseed rape were at minimum tillage and that was $258.37 €$ per ton (variant $\mathrm{N}_{150}$ ) and $259.81 €$ per ton (variant $\mathrm{N}_{200}$ ). Very low yields of winter oilseed rape were reached at direct sowing variant and the production of 1 ton of seeds cost $400.14 €$ on variant $\mathrm{N}_{150}$ and for $372.41 €$ on variant $\mathrm{N}_{200}$.

Economic effectiveness of winter rape production depends on the price of seed. Variant with minimum tillage was most profitable at both fertilization levels, namely with subsidies $\left(309.50 € \mathrm{ha}^{-1}\right.$ on variant $\mathrm{N}_{150}$ resp. $309.10 € \mathrm{ha}^{-1}$ on variant $\mathrm{N}_{200}$ ) but also without them (157.84 $€ \mathrm{ha}^{-1}$ on variant $\mathrm{N}_{150}$ resp. $157.44 € \mathrm{ha}^{-1}$ on variant $\mathrm{N}_{200}$ ). Lower gain was at conventional tillage with subsidies $\left(175.05 € \mathrm{ha}^{-1}\right.$ on variant $\mathrm{N}_{150}$ resp. $211.12 € \mathrm{ha}^{-1}$ on variant $\mathrm{N}_{200}$ ) and without subsidies (23.39 $€ \mathrm{ha}^{-1}$ on variant $\mathrm{N}_{150}$ resp. $59.46 € \mathrm{ha}^{-1}$ on variant $\left.\mathrm{N}_{200}\right)$. Production of winter rape in heavy soils by no tillage with direct sowing is economically ineffective according to our results. This type of rape cultivation represents loss without subsidies $\left(-233.69 € \mathrm{ha}^{-1}\right.$ on variant $\mathrm{N}_{150}$ resp. $-191.51 €$ ha $^{-1}$ on variant $\left.\mathrm{N}_{200}\right)$, but also with subsidies $\left(-82.03 € \mathrm{ha}^{-1}\right.$ on variant $\mathrm{N}_{150}$ resp. $-39.85 € \mathrm{ha}^{-1}$ on variant $\mathrm{N}_{200}$ ).

Economic effectiveness of winter rape production depends on realization price of its seed yield. The variant of minimum tillage was the most profitable at both fertilization levels, either with or without subsidy. Lower profit was noticed for conventional tillage. Production of winter rape on heavy soils by non-tillage with direct sowing is economically ineffective due to our obtained yields.

\section{REFERENCES}

ABRHAM, Z. - KOVÁŘOVÁ, M. - KOCÁNOVÁ, V. HEROUT, M. - SCHEUFLER, V. 2007. Technické a tech- nologické normativy pro zemédělskou výrobu [Technical and technological limits for agricultural production]. Praha : VÚZT , 2007, no. 5, 29 p. ISBN 978-86884-26-4

BALLA, P. - KOTOROVÁ, D. 2003. Vplyv spracovania pôdy na úrody obilnín $\mathrm{v}$ podmienkach Východoslovenskej nížiny [Effect of soil tillage on grain crops yields in the East-Slovakian Lowland conditions]. In Agriculture (Pol'nohospodárstvo), vol. 49, 2003, no. 5, pp. 243-249.

BUCHTA, S. 2010. Dopadové efekty podporných programov na pol'nohospodárstvo a rozvoj vidieka [Impact of supporting programs on agriculture and rural development]. In Ekonomika pol'nohospodárstva (Economics of Agriculture), vol. 10, 2010, no. 2, pp. 13-17.

DANILOVIČ, M. - ŠOLTYSOVÁ, B. 2007. Obrábanie pôdy vo vzt’ahu k úrode a kvalite zrna jačmeňa siateho jarného [Soil cultivation and its effect on grain yield and quality parameters in spring barley]. In Agriculture (Polnohospodárstvo), vol. 53,2007 , no. 2 , pp. 102-108.

DOBEK, T. 2005a. Economical assessment and energy requirement of various technologies of winter rape production. In Inżynieria Rolnicza, vol. 10, 2005, no. 3, pp. 125-132.

DOBEK, T. 2005b. Assessment of economics and energy requirement of various technologies of soil preparation for winter rape planting. In Inżynieria Rolnicza, vol. 10, 2005, no. 3, pp. 133-140.

ĎURIČOVÁ, I. - CHRASTINOVÁ, Z. 2010. Podpora pol'nohospodárstva a rozvoja vidieka na Slovensku [Support to agriculture and rural development in Slovakia]. In Ekonomika pol'nohospodárstva (Economics of Agriculture), vol. 10, 2010, no. 2, pp. 3-12.

HNÁT, A. 2009. The dependence of grain maize yield (Zea mays L.) from different soil tillage and meteorological conditions. In Agriculture (Pol'nohospodárstvo), vol. 55, 2009, no. 3, pp. 148-155.

JAMBOR, M. 2007. Vplyv výsevku a termínu sejby na tvorbu úrody vybraných odrôd a hybridov repky ozimnej [Effect of sowing rate and sowing date on creation of yield of selected winter oilseed rape varieties and hybrids]. In Agriculture (Pol'nohospodárstvo), vol. 53, 2007, no. 1, pp. 49-57.

KÁTAI, Z. 2009. Soil tillage systems as an abiotic factor in the production of oilseed rape (Brassica napus L.). In Cereal Research Comunications, vol. 37, 2009, no. 3, pp. 411-414.

KÁTAI, Z. 2010. Effect of ecological and agrotechnical elements in resilience of rape (Brassica napus L.) production. In Növénytermelés, vol. 59, 2010, no. 4, pp. 361-364.

KAVKA, M. 2006. Normativy zemédělských výrobnich technologii [Limits of agricultural production technologies]. Praha : ÚZPI, 2006, 376 p. ISBN 80-7271-164-4

KOVÁČ, L. - GEJGUŠ, J. 2002. Vplyv spôsobu založenia porastu na produkciu sušiny d'atelinotrávnych miešaniek [The effect of way of stand establishment on dry matter production of clover-grass mixtures]. In Agriculture (Polnohospodárstvo), vol. 48, 2002, no. 12, pp. 625-631.

KUBANKOVÁ, M. - BURIANOVÁ, V. 2008. Náklady a výnosy pol'nohospodárskych výrobkov v SR za rok 2007 $v$ triedení podl'a výrobných oblastí [Costs and revenues of agricultural products in Slovakia in 2007 according to production areas classification]. Bratislava : VÚEPP, 2008. 66 p. ISBN 978-80-8058-492-4 
LINKEŠ, V. - PESTÚN, V. - DŽATKO, M. 1996. Príručka pre použivanie máp bonitovaných pôdno-ekologických jednotiek [Manual for using of maps of site pedo-ecological units]. 3. vyd. Bratislava : VÚPÚ, 1996. 103 pp. ISBN 8085361-19-1

NOZDROVICKÝ, L. - RATAJ, V. 2001. Porownawca ocena dwóch sposóbow uprawy rzepaku zimego [Comparison of two ways of winter rape cultivation]. In Problemy inzynierii rolniczej na progu III tysialecia. Szczecin: Instytut Inzynierii Rolniczej Akademii Rolniczej, 2001, pp. 208212.

POLÁČKOVÁ, J. - BOUDNÝ, J. - JANOTOVÁ, B. - NOVÁK, J. 2010. Metodika kalkulaci nákladů a výnosů $v$ zemédélství [Methodics for costing of costs and returns in agriculture]. Praha : ÚZEI , 2010, 58 p. ISBN 978-8086671-75-8

SERENČÉŠ, P. - TÓTH, M. - ČIERNA, Z. 2009. Dotácie v pol’nohospodárstve a ich vplyv na výsledok hospodárenia pol'nohospodárskych podnikov na Slovensku [Subsidies in Agriculture and their Influence on Profitability of Slovak Agricultural Enterprises]. In Acta oeconomica et informatica, vol. 12, 2009, no. 1, pp. 1-5.

SYROVÝ, F. - BAUER, F. - GERNDTOVÁ, I. - HOLUBOVÁ, V. - HŮLA, J. - KOVAŘÍČEK, P. - KROUHLÍK, M. KUMHÁLA, F. - KVÍZ, Z. - MAŠEK, J. - PASTOREK, Z. - PODPĚRA, V. - RYBKA, A. - SEDLÁK, P. - SKALICKÝ, J.-ŠMERDA, T. 2008. Úspory energie v technologiich rostlinné výroby [Energy savings technologies in crop production]. Praha : VÚZT, 2008, 101 p. ISBN 97880-86884-44-8

ŠARIKOVÁ, D. - HNÁT, A. 2005. Yield of pea cultivated under the conventional agrotechnics sowing into no-tilled soil. In Agriculture (Polnohospodárstvo), vol. 51, 2005, no. 5 , pp. 267-273.

ŠAŘEC, P. - ŠǍ̌EC, O. - DOBEK, T. - HORÁK, L. 2009. Analysis of winter rape production depending on technology employed to prepare soil for sowing. In Inżynieria Rolnicza, vol. 13, 2009, no. 1, pp. 265-272.

ŠROJTOVÁ, G. 2002. Pestovanie ozimnej repky olejnej na Východoslovenskej nižine [The cultivation of winter rape on the East Slovak Lowland]. Michalovce : OVÚA, 2002, 78 p. ISBN 80-968620-9-X

ŠROJTOVÁ, G. 2005. Priebeh poveternostných podmienok a ich vplyv na tvorbu úrody repky olejky [Course of weather and its influence on yield formation of winter rape). In Proceeding of scientific works of the Research Institute for Plant Production -Institute of Agroecology Michalovce. Michalovce : RIPP-IA, 2005, no. 21. ISBN 80-88790-44-1, pp. $15-22$.

ZUBAL, P. 2003. Vplyv vybraných agrotechnických faktorov na úrody ozimnej repky olejky [The effect of selected growing factors on yield of winter oilseed rape]. In Agriculture (Polnohospodárstvo), vol. 49, 2003, no. 12, pp. 597-607.

Received: April, $12^{\text {th }}, 2011$ 